\title{
A 100-Year Review: A century of dairy heifer research ${ }^{1,2}$
}

\author{
A. J. Heinrichs, ${ }^{* 3}$ G. I. Zanton,† G. J. Lascano, $\ddagger$ and C. M. Jones* \\ *Department of Animal Science, The Pennsylvania State University, University Park 16802 \\ †USDA-Agricultural Research Service, US Dairy Forage Research Center, Madison, WI 53706 \\ $\ddagger$ Animal and Veterinary Sciences Department, Clemson University, Clemson, SC 29634-0311
}

\section{ABSTRACT}

The years 1917 to 2017 saw many advances in research related to the dairy heifer, and the Journal of Dairy Science currently publishes more than 20 articles per year focused on heifers. In general, nutrition and management changes made in rearing the dairy heifer have been tremendous in the past century. The earliest literature on the growing heifer identified costs of feeding and implications of growth on future productivity as major concepts requiring further study to improve the overall sustainability of the dairy herd. Research into growth rates and standards for body size and stature have been instrumental in developing rearing programs that provide heifers with adequate nutrients to support growth and improve milk production in first lactation. Nutrient requirements, most notably for protein but also for energy, minerals, and vitamins, have been researched extensively. Scientific evaluation of heifer programs also encouraged a dramatic shift toward a lower average age at first calving over the past 30 yr. Calving at 22 to 24 mo best balances the cost of growing heifers with their production and lifetime income potential. Increasingly, farms have become more progressive in adopting management practices based on the physiology and nutrient needs of the heifer while refining key economic strategies to be successful. Research published in the Journal of Dairy Science has an integral role in the progress of dairy heifer programs around the world.

Key words: dairy heifer, growth, age at first calving, heifer nutrition

\footnotetext{
Received April 7, 2017.

Accepted August 4, 2017.

${ }^{1}$ This review is part of a special issue of the Journal of Dairy Science commissioned to celebrate 100 years of publishing (1917-2017).

${ }^{2}$ Mention of any trademark or proprietary product in this paper does not constitute a guarantee or warranty of the product by the USDA or the Agricultural Research Service and does not imply its approval to the exclusion of other products that also may be suitable.

${ }^{3}$ Corresponding author: ajh@psu.edu
}

\section{INTRODUCTION}

The years 1917 to 2017 saw many great advances in research related to the dairy heifer, and in this time the industry has made many improvements to the way we grow and manage heifers (Appendix Table A1). In the earliest years of the century, the Journal of Dairy Science (JDS) had very few heifer publications - sometimes $<1$ or 2 per year related to the growing heifer. However, the later years, notably the past $20 \mathrm{yr}$, have seen a dramatic increase in heifer research publications, with 20 or more per year. This review includes publications appearing in JDS since its beginning that had the term dairy heifer in the title or key words. Papers focusing on preweaned calves and treatments applied to heifers after their first calving were excluded. Topics related to breeding and reproduction, welfare, disease, and housing and facilities are not covered to limit duplication with other articles in this issue of JDS.

In the earliest literature on the growing heifer, researchers identified costs of feeding and implications of growth on future productivity as major concepts requiring further study to improve the overall sustainability of the dairy herd. The status of knowledge of the practical feeding of dairy heifers at the time JDS was established was well summarized by Henry and Morrison (1915; page 426): "The rearing of the heifer after 6 to 8 months of age is an easy task, and perhaps because of this many are stunted for lack of suitable feed." The authors subsequently described the feeding of heifers in approximately half a page, clearly indicating opportunity for conducting and reporting additional research on growth, nutrition, and management.

\section{GROWTH}

Growth has been a fundamental outcome of interest in heifer nutrition and management research over the years. Eckles (1920) and Ragsdale (1934) published the first growth standards for dairy heifers at the University of Missouri; standards from USDA Beltsville (Matthews and Fohrman, 1954) and the University of Nebraska (Davis and Hathaway, 1956) followed. Most were derived from a single experiment station herd over 
a period of years, yet all were quite similar in their outcome. In many early heifer studies, researchers characterized growth relative to a "standard" or "normal" heifer using 1 of these reports. There are even instances in which a control group was not included in an experiment because comparisons could be made with such a standard (Maynard and Norris, 1923). Also of interest, in this early period of research many articles contained pictures of the animals on study to supplement growth data with a visual representation of the form of growth. These practices emphasize 2 important concepts of this early work: experiments consistently contained a very small number of animals, and appropriate controls rarely were included.

In one of the earliest reports of growth, McCandlish published measurements from birth to production age and showed that BW consistently increased proportionally to the product of height, depth, and width (McCandlish, 1922). Likewise, height:weight ratio was suggested to maintain a constant proportionality independent of age (Brody and Ragsdale, 1922). Much later, Swanson et al. (1967) published an estimate of optimal growth patterns for dairy heifers. Twenty years after this, Heinrichs and Hargrove (1987) published Holstein heifer weight and height growth standards derived from population studies that showed that heifers were larger than previously published standards, which likely represented changes in breeding programs over time. In addition, they published population growth studies of other dairy breeds from 2 to 24 mo of age (Heinrichs and Hargrove, 1991, 1994). These were (and still are) the most comprehensive publications of growth standards for these breeds.

Summaries of data by Kertz et al. (1998) provided descriptions of Holstein growth through the heifer development phase. Growth rate was fastest in the first 6 mo of life, and feed cost per unit of BW or withers height was lowest during this time. Heinrichs et al. (1992) showed equations predicting BW from other body measurements and published a modified heart girth to BW equation, likely reflecting changes in conformation from early standards (Ragsdale, 1934; USDA/Matthews and Fohrman, 1954). Taking this concept further, Oliveira et al. (2013) developed an equation using heart girth to estimate BW for crossbred Holstein-zebu heifers in Brazil.

Early studies began to relate growth to production and later to economics. Growth from birth to 2 yr was uncorrelated with first-lactation or lifetime-lactation performance (Davis and Willett, 1938). In contrast, Plum et al. (1952) documented a positive relationship between growth of chest girth and butterfat production; however, this relationship was suggested to have been attributable to environmental factors instead of genetics. This same study reported a positive genetic correlation between growth in withers height and butterfat production. Touchberry (1951) and Blackmore et al. (1958) reported a negative genetic association between body size measurements and milk production, with the exception of a positive correlation between withers height and production in the latter study. With the limited data available, it was noted that there was a correlation (44 comparisons, $\mathrm{r}=+0.40$ ) between $\mathrm{BW}$ gain during the last 2 mo of pregnancy and subsequent lactation performance regardless of season of calving (Blackmore et al., 1958).

Further studies on growth looked at the genetic relationships of growth and production. Koenen and Groen (1996) estimated the genetic relationship between BW at first calving and other growth patterns and found that estimated mature BW was negatively correlated with rate of maturation, whereas $\mathrm{BW}$ at first calving had a strong correlation with mature BW and a negative correlation with maturation rate. Coffey et al. (2006) studied growth of dairy heifers from 2 genetic lines in the United Kingdom: selection for maximum production of fat and protein (select) or average production (control). Under the same management, heifers from the select line grew faster and were heavier at first calving. However, Van de Stroet et al. (2016) showed that larger heifers were not superior in production compared with average-sized animals.

Swanson published a series of papers in the 1960s reporting heifer growth and its relationship to future production (Swanson and Hinton, 1964; Swanson et al., 1967; Swanson, 1971). This helped support his definition that an optimal growth pattern for dairy heifers will develop their full lactation potential at the desired age with minimum expense. Many of these early growth studies used twins to minimize genetic differences, and many of these studies were done with a limited number of animals, often with a variety of breeds. Swanson and Hinton (1964) restricted growth of twin heifers by $25 \%$, and although first-lactation production was 78 to $95 \%$ that of the normal-growth heifers, in second and third lactations the pairmates produced almost alike, showing no harmful effect of subnormal growth after the first lactation. However, size of the restricted-growth animals was smaller through maturity. Swanson et al. (1967) studied slowly grown heifers versus those grown at normal rates of gain. Their results showed that prepartum supplementation of the slowly grown heifers allowed them to attain, if not exceed, normal lactation performance. On this basis, liberal prepartum feeding for 9 to 12 wk before expected calving was recommended for heifers if they were substandard in size.

Gardner et al. (1977) published the first work on accelerated growth and early breeding of heifers. They in- 
creased ADG from weaning to breeding and accelerated heifers calved at 19.7 mo, 7.2 mo earlier than control heifers. Accelerated heifers produced significantly less milk in first lactation and numerically less in following lactations. Interestingly, the authors provided little to no discussion of the results. Kertz et al. (1987) showed that growth of Holstein heifers can be accelerated up to $1 \mathrm{~kg}$ of ADG from 3 to 12 mo of age without excessive fattening. Several studies evaluated prepubertal ADG and first-lactation milk production, often with differing conclusions. Zanton and Heinrichs (2005) conducted a meta-analysis of heifer growth and production studies and found a quadratic relationship, which demonstrated that the conclusions of each study were tied to the ADG chosen. The reported optimal ADG was $799 \mathrm{~g} / \mathrm{d}$ before puberty.

\section{AGE AT CALVING}

In reference to growth and management effects on age at first calving (AFC), a progression of research has demonstrated the economic importance of this aspect of heifer raising. In the first year of JDS, cows calving at later than $30 \mathrm{mo}$ of age were shown to have produced more milk in 2 lactations than cows calving earlier than 30 mo did in 3 lactations (White, 1917). This was shown by following 10 cows that calved for the first time over an 8.3-yr period and were not randomly assigned to early or late treatments. In an observational study, Plum and Lush (1934) reported that average AFC in the Iowa Cow Testing Association registry was $27.1 \mathrm{mo}$, with a median age of $25.33 \mathrm{mo}$. These data also showed that half of the purebred calves in this analysis were born to dams that were $<52$ mo of age. Similarly, the average age of a cow was reported to be $56.4 \mathrm{mo}$ in the Iowa Cow Testing Association using broader inclusion criteria than were used previously (Cannon and Hansen, 1939). These data indicated that an average cow spends a substantial proportion of her life in the unproductive state. Thus, management factors that reduced the time or increased the efficiency of raising heifers from weaning to first calving without negatively affecting future productivity could positively influence profitability of dairy farms. It should be noted that much of the research in the area of age at calving does not take into account the length or number of lactations or age of animal life.

In a review of heifer growth and production research, Schultz (1969) stated that there appeared to be a trend in more recent publications to revise the breeding age downward. Schultz discussed research on the effects of alterations in the rearing system from the "standard" or "normal" procedures to make recommendations for lowering AFC. Powell (1985) published a review of AFC trends covering 1960 to 1982 . Means and distributions were similar for all breeds, and the distribution of AFC was skewed toward higher AFC for all breeds. Ayrshires had the highest mean AFC, and Jerseys had the lowest. Mean AFC changed little from the early 1960s to the early 1980s, although it peaked slightly around 1976 . Powell's (1985) data showed that AFC decreased about $3 \mathrm{~d} / \mathrm{yr}$ from the mid 1970s through 1982. Later work showed that trend (AFC decreasing $3 \mathrm{~d} / \mathrm{yr}$ ) continuing in the Holstein breed from 1985 to 1990 (Heinrichs and Vazquez-Anon, 1993).

Breeding heifers at a younger age coupled with a proper rearing program offers a promising approach to increase profit for the dairy industry. Lin et al. (1986) showed that breeding heifers as early as $350 \mathrm{~d}$ of age had no adverse effects on calving ease or retained placenta but did result in calves that were $1.2 \mathrm{~kg}$ lighter at birth. Heifers of the 350-d breeding group had lower milk production but were the same size at all points as heifers bred at $462 \mathrm{~d}$. When lactation performance was analyzed, a reduction of 1 mo in AFC increased 3-parity and 61-mo total milk by 427 and $554 \mathrm{~kg}$, respectively (Lin et al., 1988). Gardner et al. (1988) observed no differences in reproduction or production in heifers managed to achieve early or late AFC. Results from these studies suggested that early breeding was a viable and practical approach to improving profitability. The industry responded with a strong trend in reducing AFC from this point onward. However, Mohd Nor et al. (2013) showed that calving earlier on Dutch farms resulted in less milk in first lactation, indicating that management changes must accompany breeding at earlier ages.

Heinrichs et al. (1994) reported results of the National Dairy Heifer Evaluation Project, the first epidemiological study of the national dairy industry conducted by USDA. In this survey, operations with mean BW $>545$ $\mathrm{kg}$ at first calving and AFC $\leq 27$ mo had higher milk production. Hare et al. (2006) examined AFC from 1980 through 2004 and found that it declined progressively with time for all 5 breeds studied. Jerseys had the lowest AFC, and it declined from $26.5 \mathrm{mo}$ in 1980 to $24 \mathrm{mo}$ in 2004. Ayrshires had the highest AFC at 29 mo in 1980 and 28.5 mo in 2004. Holstein AFC was 28 mo in 1980 and decreased to 25.5 mo by 2004 . The distribution also shifted to the left during this period, with almost $20 \%$ of heifers calving at 24 mo in 2004 compared with approximately $8 \%$ in 1980 .

Results of studies conducted in multiple states and countries investigating optimum AFC are remarkably consistent. Gill and Allaire (1976) using Ohio data showed that optimal AFC for total lifetime production was 22.5 to 23.5 mo. Hoffman and Funk (1992) proposed that 22 to 24 mo was the best AFC; calving ear- 
lier resulted in reduced milk yield. In Italian HolsteinFriesians, an AFC between 23 and 24 mo was found to best balance rearing costs and milk yield (Pirlo et al., 2000). In California Holsteins, the highest economic return was generated for AFC from 23 to 24.5 mo when considering milk production, stillbirths, reproduction, and health (Ettema and Santos, 2004). Nilforooshan and Edriss (2004) observed that milk yield in Iranian Holsteins increased as AFC increased from 21 to 24 mo but decreased as AFC extended past 24 mo; they determined that the optimum AFC was 24 mo. In Pennsylvania the most efficient heifer-raising programs had AFC of 23.7 mo and first-lactation animals producing $88.42 \%$ of the milk produced by multiparous cows (Heinrichs et al., 2013).

Simerl et al. (1991) showed that Florida herds were calving at 22.2 mo of age without issues at parturition. Bach et al. (2008) compared 47 dairy herds in Spain that fed the same lactation ration but were under individual management and had a range of $13 \mathrm{~kg} / \mathrm{d}$ in average milk production. Four factors, including AFC of heifers, accounted for more than $50 \%$ of the variation in milk production observed between these herds. Mohd Nor et al. (2013) introduced relative AFC (the difference between AFC of an individual and median $\mathrm{AFC}$ of the herd) as a new way of evaluating the effect of AFC. Dutch heifers calving 1 mo earlier than the median AFC produced $90 \mathrm{~kg}$ less milk per $305 \mathrm{~d}$; those calving 1 mo later produced $86 \mathrm{~kg}$ more. This measurement assumed that heifers had the same management within a herd, and a heifer's deviation from the median reflected her development. Thus, earlier breeding without adjusting management to ensure adequate development was shown to reduce first-lactation production. Krpálková et al. (2014) reported that AFC $<23$ mo did not negatively affect milk yield or reproduction parameters during the first 3 lactations. Other than the normal known factors, AFC in heifers and level of milk production during gestation in cows were indicated as decisive determinants of calf birth size (Kamal et al., 2014). Thus, we can see the progression of a downward trend in AFC worldwide. Current genetics of the Holstein breed and management of commercial farms will allow the breed to reach at least $22 \mathrm{mo} \mathrm{AFC}$ on average.

\section{NUTRIENT REQUIREMENTS}

Determining nutrient requirements of heifers was the subject of much research throughout the first 100 yr of JDS. Early on, the maintenance energy requirement of young growing Holsteins was determined to be approximately $90 \%$ of that previously reported by Armsby (Eckles et al., 1927). Eckles suggested that this discrepancy was attributable to Armsby's (1917) use of beef cattle in deriving maintenance values. Mixed diets marginally improved heifer growth and improved first- and second-lactation production compared with alfalfa-only diets when heifers were fed the test diets starting at about $315 \mathrm{~kg}$ of BW (Woll, 1918). Supplementing a winter ration of alfalfa hay with barley grain increased winter growth compared with heifers fed alfalfa hay only (Willard, 1932). In this study, growth was compared with Eckles' "normal." Further study at the Wyoming station demonstrated that increased consumption of alfalfa hay was obtainable by increasing the hay allowance and decreasing the grain allowance (Willard, 1938).

Feedstuff digestibility for Holstein heifers fed diets that contained no roughage (Mead and Goss, 1935) was shown to be consistent with what would be calculated from ingredient digestibility coefficients determined from the book values of Henry and Morrison (1923), which had been determined when forage was fed. Differing hay quality grades affected gains and feed efficiency (Kelkar and Gullickson, 1950; Gordon et al., 1954, 1956); however, it was noted that the current chemical and physical analyses were insufficient to completely characterize the value of hays for heifer growth (Gordon et al., 1952). Donker et al. (1968) published a method for evaluating forage energy production formulas by comparing various published energy intake estimates with heifer requirements. They reported that of the 9 equations used to estimate forage energy, all were inadequate for differentiating the ability of hay qualities to stimulate heifer growth. Corn silage was found to be inferior to grass silage as the sole source of forage, although heifer growth was improved if a small amount of grass hay was added to either ration (Keener et al., 1958).

Reid and Robb (1971) evaluated the relationship of body composition to energy intake and energetic efficiency. Their work showed that body protein and fat were linearly related to empty BW; furthermore, body protein and fat explained 99.7 and $96.1 \%$ of the variation in empty BW, respectively. They used 61 heifers from $1 \mathrm{~d}$ to 14 mo of age and provided a wide range of body composition data covering 4 different breeds and crosses fed a variety of nutritional regimens. In the same year, Swanson (1971) investigated feed energy requirements of heifers under different rates of growth. Data for this meta-analysis came from 16 experiments involving more than 900 heifers in 267 experimental groups, within which heifers had been fed to produce different growth rates. He published a prediction equation based on diet TDN and BW that was reported to apply to all dairy breeds from 4 to 22 mo of age. Fox et al. (1999) evaluated the applicability of the beef NRC (1996) equations for predicting growth requirements, 
target weights based on mature size, and energy reserves in dairy cattle. Coefficients of the equations were modified, but the methods were accurate when predictions were compared with actual observations for heifers $>100 \mathrm{~kg}$. With slight modifications, this system was adopted by the next edition of the dairy NRC (2001).

\section{Protein}

Early research evaluated using homegrown protein supplements to reduce costs of providing protein to growing heifers. Hilton et al. (1932) demonstrated that raw soybeans could effectively replace linseed oil meal when fed for approximately $1 \mathrm{yr}$ in a diet containing alfalfa hay as the source of forage. Subsequently, heifers were found to grow equally well on diets containing either steam-dried or flame-dried fish meal (Berry and Manning, 1936). Results based on weight gains alone provide little insight into the nutritional mechanisms affecting an increased ADG or the effect of protein quality on ADG. Hart et al. (1939) initiated studies that evaluated the ability of the growing ruminant animal to use NPN supplements to increase the CP content of a CP-deficient diet. In one of the first studies of its kind, a rumen-fistulated Holstein heifer was used to demonstrate the conversion of dietary urea to protein in the rumen (Wegner et al., 1941a). Further work with the fistulated Holstein heifer demonstrated that conversion of urea to protein was affected by the protein (Wegner et al., 1941b), starch (Mills et al., 1942), and soluble sugar (molasses; Mills et al., 1944) contents of the basal diet. Growth studies showed that although urea could be used as a source of $\mathrm{CP}$, the $\mathrm{N}$ from urea was not used as effectively as the $\mathrm{N}$ from soybean meal (Bohman et al., 1954; Lassiter et al., 1958) or when urea was included in a molasses-containing diet compared with a corn-containing diet (Bohman et al., 1954; King et al., 1957). In heifers fed low-protein diets, feeding high energy markedly increased the retention of $\mathrm{N}$ that was available for growth (Lofgreen et al., 1951). Later researchers from New Hampshire also studied urea utilization. Using 3 sets of twins in a respiration chamber, Colovos et al. (1963) showed that including urea in limited amounts was beneficial in higher forage rations.

Some interesting work from the late 1970s and early 1980s evaluated unusual alternative protein and energy sources. Johnson and McCormick (1975) fed municipal waste with sorghum silage, and Cross and Jenny (1976) fed turkey litter silage. Block and Shellenberger (1980) fed wood fines, and Keys and Smith (1981) fed poultry litter. All found adequate growth when diets were balanced; however, this line of research did not seem to go further, likely because of the questionable welfare of heifers fed these types of alternative feedstuffs.

Since the 1990s a great deal of dairy heifer nutrition research has been conducted, much of it related to updating protein requirements with little emphasis on energy. In general, these studies had reasonably large numbers of animals and adequate controls, unlike some of the earlier work. A variety of research groups studied total protein intake as it relates to diet energy. Lammers and Heinrichs (2000) used a CP:ME ratio of 46:1, 54:1, or $61: 1 \mathrm{~g} /$ Mcal and found a linear increase in ADG, feed efficiency, and structural growth with increasing CP:ME ratio. Hoffman et al. (2001) investigated 8, 11,13 , or $15 \% \mathrm{CP}$ in similar energy diets; structural growth, $\mathrm{N}$ retention, and diet digestibility were maximized at 13\% CP. Gabler and Heinrichs (2003) fed a CP:ME ratio of $48.3,59.1,67.5$, or $76.5 \mathrm{~g} / \mathrm{Mcal}$ at DMI allowing an ADG of $800 \mathrm{~g} / \mathrm{d}$; feed efficiency and height improved linearly with increasing CP:ME ratio. Marini and Van Amburgh (2005) observed that low-N diets reduced urine excretion of $\mathrm{N}$, whereas growth rates were maintained. These studies showed that altering the CP: energy ratio of heifer diets improved growth and feed efficiency.

Research on the effects of protein degradability on growth has begun relatively recently. Petit and $\mathrm{Yu}$ (1993) fed heifers fresh grass (timothy-clover mix) ad libitum with no supplemental N, a high-NPN molasses block, or high-RUP block containing animal proteins. Protein supplementation increased ADG, but no difference was observed between blocks, so the authors concluded that RUP was not the limiting factor. Casper et al. (1994), using 3-mo-old Holstein heifers, found that ADG improved in diets with extruded soybean meal, with greater improvement in diets containing barley versus corn. They recommended 35 to $40 \%$ RUP for heifers 3 to 6 mo of age. Bethard et al. (1997) used 32 heifers fed rations formulated for an ADG of 0.6 or 0.9 $\mathrm{kg} / \mathrm{d}$ with 30 or $50 \%$ of CP as RUP from age 6 to 13 mo and found improved feed efficiency for high-energy and high-RUP diets. However, Steen et al. (1992) and Swartz et al. (1991) found no growth advantage to increasing the undegradable protein intake of heifers, as was noted in the 1989 NRC (NRC, 1989). Daccarett et al. (1993) fed Holstein heifers 107 or $124 \%$ of NRC requirements for $\mathrm{CP}$ and $\mathrm{ME}$ from 3 to 6 mo of age and 100 or $115 \%$ from 6 to 24 mo and demonstrated that feeding in excess of NRC (1989) recommendations increased BW and height without fattening. Van Amburgh et al. (1998) evaluated NRC (1989) and Cornell Net Carbohydrate and Protein System recommendations using 273 Holsteins with ADG treatments of 0.6, 0.8, or $1.0 \mathrm{~kg} / \mathrm{d}$ from 90 to $320 \mathrm{~kg}$ of BW. Actual ADG 
were $0.68,0.83$, and $0.94 \mathrm{~kg} / \mathrm{d}$ and were not affected by feeding plant and animal or plant and urea protein sources. They also showed, consistent with several previous studies, that NRC underestimated RDP and overestimated RUP requirements. Zanton and Heinrichs (2008a) published a meta-analysis of $\mathrm{N}$ utilization and excretion in weaned dairy calves that summarized 10 experiments with 57 different treatments. True N digestibility was estimated at $96.4 \%$, and endogenous, nondietary fecal $\mathrm{N}$ excretion was $6.51 \mathrm{~g}$ of $\mathrm{N} / \mathrm{kg}$ of DMI. Diet CP of $14.2 \%$ and N intake of $1.84 \mathrm{~g} / \mathrm{kg}$ of metabolic BW maximized gross $\mathrm{N}$ efficiency. They concluded that reductions in fecal $\mathrm{N}$ excretion would be most achievable through reduced DMI while feeding a high enough concentration of energy to meet the needs of the animal. Reducing urinary $\mathrm{N}$ excretion is best accomplished by decreasing $\mathrm{N}$ intake. In a follow-up study (Zanton and Heinrichs, 2009), Holsteins of $362 \mathrm{~kg}$ of BW and 12.3 mo of age were fed 25 or $75 \%$ forage diets with $0.94,1.62,2.30$, or $2.96 \mathrm{~g}$ of $\mathrm{N} / \mathrm{kg}$ of metabolic BW and equal energy intakes. Their results suggested that feeding $1.67 \mathrm{~g}$ of $\mathrm{N} / \mathrm{kg}$ of metabolic BW optimized $\mathrm{N}$ efficiency regardless of the forage level in the ration. Lascano et al. (2012) used those levels of $\mathrm{N}$ to evaluate starch digestibility and found that high starch decreased ADF and increased hemicellulose digestibility. Lascano et al. (2016) concluded that low fiber levels in low- and high-forage diets increased utilization of nutrients under limit-feeding conditions when provided with high RDP. Furthermore, Zanton and Heinrichs (2016) reported that heifers limit-fed high-energy diets had increased digestibility and $\mathrm{N}$ retention and that younger animals were more responsive to this feeding strategy.

\section{Vitamins and Minerals}

The early research on vitamins for dairy heifers occurred closely in parallel with the development of the understanding of the importance of vitamins in overall nutrition. The first evidence that the knowledge of the chemical composition of feeds was incomplete was determined when researchers fed rations comprising a single plant source (corn, wheat, or oats) to dairy heifers, resulting in differences in offspring vigor and milk production capacity even though the chemical compositions of the rations were, in all known respects, identical (Hart et al., 1911). Several studies were subsequently reported detailing vitamin requirements of heifers. Vitamin A was shown to be indispensable for the normal growth and development of calves (Jones et al., 1926). However, calves could grow and reproduce normally on a ration that contained vitamin $\mathrm{B}$ insufficient to support the growth and well-being of rats; the deficit in dietary vitamin $\mathrm{B}$ was proposed to be synthesized by the rumen bacteria (Bechdel et al., 1926). Likewise, heifers were shown to grow normally for $1 \mathrm{yr}$ on a ration that resulted in death from scurvy of guinea pigs in less than $30 \mathrm{~d}$ (Thurston et al., 1926), indicating that heifers can synthesize sufficient vitamin C. Calves grown from birth to first calving in the dark grew normally (Gullickson and Eckles, 1927). However, these calves were provided with ad libitum access to timothy hay, which was subsequently shown to prevent rickets when sun cured but not when cured in the dark (Huffman et al., 1935). The forage component of the heifer diet was suggested to be a significant contributor to the vitamin and mineral requirements of heifers when a diet devoid of roughage was able to support normal growth when supplemented with cod liver oil and alfalfa ash (Mead and Regan, 1931; Wise et al., 1939). Previously, it was unclear whether the deficiency in a roughage-free diet was attributable to a lack of bulk in the diet or a vitamin or mineral deficiency (McCandlish, 1923). More recently, biotin supplementation of heifers precalving and during first lactation did not affect incidence of lameness (though it did for cows of greater parity; Hedges et al., 2001), and no improvement in immune function was detected in heifers fed a source of vitamin $\mathrm{C}$ after being transported for $2.3 \mathrm{~h}$ (Tyler and Cummins, 2003). In addition, studies showed that vitamin D could be administered effectively using mucosal absorption (Okura et al., 2004; Rivera et al., 2005).

As bone diseases were not uncommon in developing dairy heifers, a description was made of normal bone from 60 to $180 \mathrm{~d}$ (Kruger and Bechdel, 1928). Bone meal supplemented to heifers for approximately 18 mo was said to be without effect compared with when heifers were supplemented with common salt (Salmon and Eaton, 1925). Diets low in $\mathrm{P}(0.2 \% \mathrm{DM})$ resulted in reduced ADG; however, reproduction was not compromised compared with a group fed a diet with adequate P (0.4\% DM; Huffman et al., 1933). Noller et al. (1977) evaluated the ability to meet $\mathrm{P}$ requirements from natural feedstuffs and the adequacy of minimums for P recommended by NRC (1971) and determined that those requirements $(0.22 \%)$ were adequate based on mineral status of the heifers and conception rates. Subsequently, Esser et al. (2009) fed diets with (0.39\% $\mathrm{P})$ or without $(0.29 \% \mathrm{P})$ supplemental $\mathrm{P}$ from 4 to 21 mo of age and found no effect of supplementation on frame measurements, bone density, or markers of bone metabolism. Similarly, Bjelland et al. (2011) found similar ADG and body measurements at 22 mo with or without supplemental P (0.4 or $0.3 \% \mathrm{DM})$ from 4 to 22 mo of age. No difference was observed in heifer reproductive performance (services per conception, age 
at conception, or dystocia) or in first-lactation milk production and reproduction; however, heifers fed supplemental P excreted more P (29.9 vs. 24.2 g/d). Ray et al. (2012) evaluated disappearance of phytate from the large intestine using heifers with ruminal and ileal cannulas using ileal infusions of $0,5,15$, or $25 \mathrm{~g}$ of phytate/d. Ileally infused phytate was degraded in the large intestine, but degradability was not dependent on the amount of phytate.

Studies showed little difference in the absorption of $\mathrm{Cu}$ from sulfate, proteinate, carbonate, or $\mathrm{Cu}-\mathrm{AA}$ complex (Du et al., 1996; Ward et al., 1996; Yost et al., 2002); however, when $\mathrm{S}$ and Mo were included in the diet, the proteinate form had better absorption than sulfate and was stored more efficiently than carbonate (Ward et al., 1996). Supplementing $\mathrm{Cu}$ in the form of sulfate or Lys also made little difference in growth, though $\mathrm{Cu}$-Lys enhanced liver and plasma $\mathrm{Cu}$ concentrations in heifers with low $\mathrm{Cu}$ status (Rabiansky et al., 1999). Holstein heifers supplemented with $\mathrm{Cu}$ sulfate or proteinate prepartum and in early lactation had improved plasma and liver $\mathrm{Cu}$ status and a less severe response to an Escherichia coli mastitis challenge in one study (Scaletti et al., 2003) and lower bacteria count in their milk in another study (Scaletti and Harmon, 2012). Sumner et al. (2007) fed 0, 5, 10, or $15 \mathrm{mg}$ of $\mathrm{Cr} / \mathrm{d}$ from 11 to 14 mo of age; increasing Cr increased glucose concentration and utilization and decreased insulin and nonesterified fatty acid (NEFA) concentration. Spears et al. (2012) reported that feeding $\mathrm{Cr}$ propionate increased tissue sensitivity to insulin and recommended providing $3 \mathrm{mg} / \mathrm{d}$ or $0.47 \mathrm{mg} / \mathrm{kg}$ of DM.

In a survey of 22 herds in Finland, Jukola et al. (1996) found that serum Se and vitamin $\mathrm{E}$ were adequate in heifers and that supplementation was not needed. However, supplementing vitamin $\mathrm{E}$ at 3,000 IU/d beginning 2 mo before calving increased blood, liver, milk, and follicular fluid levels of vitamin $\mathrm{E}$ in other reports (Bouwstra et al., 2008; Dobbelaar et al., 2010). In addition, Ceballos-Marquez et al. (2010) found that supplementing Se to Chilean Holstein-Friesian heifers precalving via a single barium selenite injection or Se yeast at $3 \mathrm{mg} /$ head daily for $45 \mathrm{~d}$ increased blood glutathione peroxidase activity and tended to reduce IMI and quarters with high SCC at calving.

Kincaid et al. (1997) fed weaned calves (6-12 wk of age) starter containing $\mathrm{Zn}$ at various concentrations from Zn-Met, Zn-Lys, or ZnO. No effects were observed on BW, DMI, or immune functions, but Met or Lys forms were absorbed and retained better than oxide. Feeding vitamin E, Zn, and Fe for $42 \mathrm{~d}$ before calving had no effect on the incidence of retained fetal membranes, but supplementing $\mathrm{Zn}$ or vitamin $\mathrm{E}$ before calving reduced days to first estrus (Campbell and Miller,
1998). Beef heifers fed a basal diet containing $15.8 \mathrm{mg}$ of $\mathrm{Mn} / \mathrm{kg}$ of DM or supplemented with $50 \mathrm{mg}$ of $\mathrm{Mn} /$ $\mathrm{kg}$ of DM had no difference in blood concentration of Mn and grew similarly; calves born to unsupplemented heifers had lower blood Mn and presented signs of $\mathrm{Mn}$ deficiency (Hansen et al., 2006). Weiss et al. (2010) reported that feeding supplemental Fe for $60 \mathrm{~d}$ before calving resulted in no differences in measures of Fe status or in milk production, but SCC was reduced with supplemental Fe.

Nennich et al. (2005) compiled data from 4 universities to update prediction equations for nutrient excretion by dairy heifers, including total manure, total $\mathrm{DM}, \mathrm{N}, \mathrm{P}$, and $\mathrm{K}$. Current accurate predictions are important because farms use these equations to comply with environmental regulations. Manure excretion for heifers was predicted based on BW and DMI using previously published data sets. Lascano et al. (2015) reported that dietary fiber modulated ammonia emissions differently on diets extremely high $(\sim 80 \%)$ and low $(\sim 20 \%)$ in forage and that methane concentration was correlated with odor intensity. Methane emissions were not reduced when corn silage with differing NDF and starch concentrations was used or when oil from extruded linseed meal was incorporated into heifer diets (Hammond et al., 2015).

\section{MANAGEMENT}

Management systems and alterations in management have long been a topic of heifer research, as reviewed by Clark et al. (1984), who summarized much of the early feeding and management research in a review of the NC-119 cooperative research group that studies dairy heifers.

\section{Feeding}

Stair-step compensatory growth strategies have fed above or below recommendations for 2 to $3 \mathrm{mo}$ and then reversed, supporting lower growth and then allowing feed-efficient, compensatory growth when animals were on a higher plane of nutrition (Choi et al., 1997; Park et al., 1998). Feed efficiency with the stair-step program was improved compared with controls (Park et al., 1998) and enhanced by including lasalocid in the diet (Ford and Park, 2001). Heifers on a compensatory program also had greater milk yield in first and second lactation (Ford and Park, 2001).

Some interest was focused on the proposal that more frequent feeding of the growing ruminant would produce faster weight gains. Clark and Keener (1962) suggested that as a result of frequent feeding, specific enzyme pathways for the metabolism of end products 
of rumination may be altered because of a change in the concentration ratios of these metabolites. In Missouri, Campbell et al. (1963) used 40 Guernsey heifers to study urea feeding and indicated that rumen adaptation to urea may be related to increased frequency of feeding. Later work (Swanson and Hinton, 1964) showed no advantage of feeding more than once a day.

Montgomery and Baumgardt (1965a, b) used heifers as a model for feed intake studies. Quigley et al. (1986a,b) evaluated factors affecting intake of heifers in intensive management and developed an equation to predict daily DMI of heifers weighing 100 to $400 \mathrm{~kg}$. Intake of DM and digestible energy was affected by BW, BW gain, ration ADF, NDF, bulk density, and ambient temperature. Hoffman et al. (2008) evaluated previously published DMI prediction equations (Quigley et al., 1986b; NRC, 2001) using observed daily pen DMI over 28 mo $(\mathrm{n}=9,275)$ and found that both equations predicted DMI reasonably well in the middle of the growth period, but both were less precise for lighter and heavier heifers. Alternative prediction equations were derived, and greatest precision was obtained with an exponential equation that included adjustment for diet NDF.

Lammers et al. (1999) adopted a concept from the beef industry and fed heifers a high-energy diet but limited DMI to meet their requirements for growth. This began a long series of studies evaluating limit feeding of heifers in Pennsylvania and Wisconsin, with additional work done in Ontario and South Dakota. Limit feeding offers a way to improve feed efficiency and reduce nutrient losses while meeting the nutrient needs of the growing heifer. Hoffman et al. (2007) fed an ad libitum (control) diet or more nutrient-dense diets at 80 or $90 \%$ of ad libitum DMI and found no difference in weight gain, structural growth, or 150-d milk production. Limit-fed heifers had higher feed efficiency and lower manure DM excretion. Zanton and Heinrichs (2008b) fed 14.5-mo-old heifers a high-forage diet at $1.25,1.50,1.75$, or $2.00 \% \mathrm{BW}$ and concluded that limit feeding increased nutrient utilization efficiency but that DMI below $1.5 \%$ of BW reduced efficiency. Green et al. (2013) measured feeding behavior in 1,049 heifers from 5 to 9 mo of age and reported that the more efficient heifers (lower residual feed intake) consumed less feed, ate more slowly, spent less time eating, had longer meals, and consumed more feed during the night and less during the afternoon. Greter et al. (2013) reported that straw with either long or short particle length increased intake when heifers were limit fed an energy-dense diet and that they preferred long straw when given the opportunity. Suarez-Mena et al. (2013) observed that chewing activities were affected by forage concentration and by the addition of distillers grains. Higher forage inclusion increased eating time and rumen digesta weight and volume, whereas feeding distillers grains increased rumination time in limit-fed heifers. Greter et al. (2015) reported that limit-fed heifers were more motivated to access a low-quality feedstuff such as straw, possibly in response to a lack of satiety or need for forage. Miller-Cushon et al. (2015) observed that the method of transitioning heifers to a novel TMR influenced sorting behavior. In their study, heifers fed a novel ration sorted against long particles and thus received a lower NDF diet.

As an alternative to limit feeding an energy-dense diet, Coblentz et al. (2015) demonstrated that lowenergy forages (eastern gamagrass haylage, chopped wheat straw, or chopped corn fodder) offered to Holstein heifers for ad libitum intake as diluting agents reduced caloric density and DMI, with heifers sorting the straw diet and, more severely, the chopped corn fodder diet.

\section{Transition to Lactation}

When conducting research into the transition period, many studies included both primiparous and multiparous cows. This has increased our understanding of the similarities and differences between heifers entering their first lactation and more mature animals. Drenching with propylene glycol (Grummer et al., 1994) or feeding diets with greater nutrient density (Minor et al., 1998; Vandehaar et al., 1999) can reduce plasma NEFA concentrations and improve energy balance (Rabelo et al., 2003) when DMI declines before calving. Although first-lactation heifers have a lower risk of ketosis and other illnesses associated with the transition period than older cows (Duffield et al., 1998b, 1999), prepartum monensin supplementation decreased BHB in early lactation regardless of parity (Duffield et al., 1998a; Petersson-Wolfe et al., 2007). In a New York study, increases in NEFA and BHB pre- and postpartum had negative effects on milk production and reproductive performance except in postpartum heifers. Heifers with NEFA $\geq 0.57 \mathrm{mEq} / \mathrm{L}$ had $488 \mathrm{~kg}$ more 305d mature-equivalent milk and $403 \mathrm{~kg}$ more milk when BHB was $\geq 9 \mathrm{mg} / \mathrm{dL}$ (Ospina et al., 2010). Heifers also seem to respond differently than cows to anionic salts. Moore et al. (2000) found that compared with +15 or 0 , diets with a DCAD balance of $-15 \mathrm{mEq} / 100 \mathrm{~g}$ of DM reduced DMI, energy balance, and BW gain and elevated liver triglyceride in heifers when fed for $24 \mathrm{~d}$ before calving. Hayirli et al. (2002) evaluated 16 studies from 8 universities and found that heifer DMI before calving was fairly constant from 3 to 1 wk before calving, at around 1.7 to $1.8 \%$ of $\mathrm{BW}$, but decreased to $1.23 \%$ of $\mathrm{BW}$ in the final week. Less overall depression 
in DMI may be one factor contributing to a lower risk of health problems in the periparturient period for heifers compared with cows. Heifer DMI was also found to be more sensitive to increased ether extract in the diet compared with cows.

Daniels et al. (2007) demonstrated that milking heifers for $3 \mathrm{wk}$ before their expected due date resulted in less edema, improved milk production and DMI, and lowered SCC after calving. In addition, training heifers to the parlor 2 wk before calving improved milk let down and reduced distress, but heifer temperament influenced the response to milking (Sutherland and Huddart, 2012). Kutzer et al. (2015) showed that training heifers habituated them to the milking routine but did not influence milk production.

\section{Hoof Health}

A study of lameness in Dutch herds (Amory et al., 2006) found that farms that fed corn silage to heifers had increased lameness in the milking herd compared with those that did not feed corn silage. In addition, heifers diagnosed with repeated cases of digital dermatitis during the rearing period showed decreased conception rates and less milk in first lactation (Gomez et al., 2015).

Danish researchers developed an oligofructose overload model for studying laminitis (Thoefner et al., 2004). This model successfully induced acute acidosis and enabled investigation of the clinical progression of symptoms and behavior and histological examination of lesions in hoof tissue (Thoefner et al., 2005; Danscher et al., 2009, 2010; Niss et al., 2009). This group also found that lameness, lesions, and abnormal conformation identified $41 \mathrm{~d}$ before calving persisted throughout first lactation (Capion et al., 2008). In addition, herd of origin and sample location affected strength of the suspensory tissue supporting the pedal bone within the claw more than induced laminitis (Danscher et al., 2010).

\section{MODELING TO IMPROVE HEIFER MANAGEMENT DECISIONS}

Modeling heifer programs has been a more recent endeavor that thus far has considered age at calving, breeding, and growth in the context of making effective management decisions. Mourits and colleagues described (Mourits et al., 1997) and then developed (Mourits et al., 2000) a dynamic programming model that would help evaluate heifer management decisions. With prepubertal ADG set at $900 \mathrm{~g} / \mathrm{d}$ and maximum postpubertal ADG at 1,100 g, the model was optimized at $20.5 \mathrm{mo} \mathrm{AFC}$ and $\mathrm{BW}$ at calving of $563 \mathrm{~kg}$. Key factors in sensitivity analysis were growth rate and reproductive performance. Penn State researchers developed a tool to collect and calculate the costs of raising a dairy heifer (Gabler et al., 2000), which averaged approximately $\$ 1,100(\$ 1.50 / \mathrm{d})$ at that time; feed costs were $62 \%$ of the total cost. This was followed by a multiple-component analysis of factors affecting the cost of raising heifers, which determined that herd cull rate and AFC had the greatest effect on the total cost (Tozer and Heinrichs, 2001). Another study incorporated nutrient variation in ration formulation for heifers (Tozer, 2000), which reduced diet cost and overfeeding of $\mathrm{CP}$ compared with more conventional methods of linear programming or adjusting requirements or rations to include a safety margin. Another published model found economic advantages to delaying the replacement of a culled cow with a heifer when fixed costs and net returns per space in the herd were low and seasonality of cow performance was high (de Vries, 2004).

\section{SUMMARY AND FUTURE DIRECTIONS}

The objective of rearing dairy replacement heifers has been described as minimizing required inputs while returning the most profitable outputs (Hoffman and Funk, 1992). To this, modern objectives must add limiting environmental impact and protecting animal welfare. To reduce inputs, a fundamental method is reducing rearing time. Early in the century and up to the 1980s, only modest progress was made in understanding dairy replacement heifer nutrient requirements and management in relation to improving growth rates and reducing AFC. However, in the past $30 \mathrm{yr}$, there has been consistent progress toward optimizing heifer growth rates and reducing AFC. It will be interesting to see how far and how long this trend continues until it plateaus. Continued research in this area should include information related to length and number of lactations as well as heifer age in the analysis.

In general, nutrition and management changes made in rearing the dairy heifer have been tremendous in the past 100 yr. The minimal amount of published heifer research likely slowed the rate of progress in the first half of the century. However, the second half has enjoyed significant basic nutrition research and applied management studies that have propelled our knowledge of the dairy heifer forward. Increasingly, farms have become more progressive in adopting management practices based on the physiology and nutrient needs of the heifer while refining key economic strategies to be successful. There remains opportunity for research to better understand the energy requirements and feed efficiency of heifers as they continue to mature at 
younger ages of life. Along with the continuing growth in farm size and custom heifer raising, the heifer operation will increasingly be managed as its own enterprise on individual farms. By integrating reproductive (sexed semen), genetic (genomic testing and strategic culling), nutrition (limit feeding or other systems) with relation to environmental impacts, and management technologies (animal handling and behavior with an emphasis on animal well-being), the heifer operation will be a critical control point for accelerating whole-farm efficiency and sustainability. Research published in JDS has clearly had and will continue to have a tremendous influence on the progress of dairy heifer programs around the world.

\section{REFERENCES}

Amory, J. R., P. Kloosterman, Z. E. Barker, J. L. Wright, R. W. Blowey, and L. E. Green. 2006. Risk factors for reduced locomotion in dairy cattle on nineteen farms in The Netherlands. J. Dairy Sci. 89:1509-1515. https://doi.org/10.3168/jds.S0022-0302(06)72218 -4 .

Armsby, H. P. 1917. The Nutrition of Farm Animals. Macmillan, New York, NY.

Bach, A., N. Valls, A. Solans, and T. Torrent. 2008. Associations between nondietary factors and dairy herd performance. J. Dairy Sci. 91:3259-3267. https://doi.org/10.3168/jds.2008-1030.

Bechdel, S. I., C. H. Eckles, and L. S. Palmer. 1926. The vitamin B requirements of the calf. J. Dairy Sci. 9:409-438. https://doi.org/ 10.3168/jds.S0022-0302(26)93912-X.

Berry, M. H., and J. R. Manning. 1936. Comparison of the feeding value of steam dried and flame dried menhaden fish meal. J. Dairy Sci. 19:663-669. https://doi.org/10.3168/jds.S0022-0302(36)93102 -8 .

Bethard, G. L., R. E. James, and M. L. McGilliard. 1997. Effect of rumen-undegradable protein and energy on growth and feed efficiency of growing Holstein heifers. J. Dairy Sci. 80:2149-2155. https://doi.org/10.3168/jds.S0022-0302(97)76161-7.

Bjelland, D. W., K. A. Weigel, P. C. Hoffman, N. M. Esser, and W. K. Coblentz. 2011. The effect of feeding dairy heifers diets with and without supplemental phosphorus on growth, reproductive efficiency, health, and lactation performance. J. Dairy Sci. 94:62336242. https://doi.org/10.3168/jds.2011-4596.

Blackmore, D. W., L. D. McGilliard, and J. L. Lush. 1958. Relationships between body measurements, meat conformation, and milk production. J. Dairy Sci. 41:1050-1056. https://doi.org/10.3168/ jds.S0022-0302(58)91049-X.

Block, E., and P. R. Shellenberger. 1980. Woodpulp fines or corn silage as roughages in complete rations or a pelleted complete ration for young dairy replacements 18 through 36 weeks of age. J. Dairy Sci. 63:2071-2079. https://doi.org/10.3168/jds.S0022-0302(80)83184 -5 .

Bohman, V. R., G. W. Trimberger, J. K. Loosli, and K. L. Turk. 1954. The utilization of molasses and urea in the rations of growing dairy cattle. J. Dairy Sci. 37:284-293. https://doi.org/10.3168/jds.S0022 -0302(54)91252-7.

Bouwstra, R. J., R. M. A. Goselink, P. Dobbelaar, M. Nielen, J. R. Newbold, and T. van Werven. 2008. The relationship between oxidative damage and vitamin E concentration in blood, milk, and liver tissue from vitamin E supplemented and nonsupplemented periparturient heifers. J. Dairy Sci. 91:977-987. https://doi.org/10 .3168/jds.2007-0596.

Brody, S., and A. C. Ragsdale. 1922. A weight-height-age curve as a measure of the state of nutrition and of growth of the dairy cow. J. Dairy Sci. 5:479-484. https://doi.org/10.3168/jds.S0022 $-0302(22) 94176-1$.
Campbell, J. R., W. M. Howe, F. A. Martz, and C. P. Merilan. 1963. Effects of frequency of feeding on urea utilization and growth characteristics in dairy heifers. J. Dairy Sci. 46:131-134. https://doi .org/10.3168/jds.S0022-0302(63)88987-0.

Campbell, M. H., and J. K. Miller. 1998. Effect of supplemental dietary vitamin $\mathrm{E}$ and zinc on reproductive performance of dairy cows and heifers fed excess iron. J. Dairy Sci. 81:2693-2699. https://doi.org/ 10.3168/jds.S0022-0302(98)75826-6.

Cannon, C. Y., and E. N. Hansen. 1939. Expectation of life in dairy cows. J. Dairy Sci. 22:1025-1032. https://doi.org/10.3168/jds .S0022-0302(39)92956-5.

Capion, N., S. M. Thamsborg, and C. Enevoldsen. 2008. Conformation of hind legs and lameness in Danish Holstein heifers. J. Dairy Sci. 91:2089-2097. https://doi.org/10.3168/jds.2006-457.

Casper, D. P., D. J. Schingoethe, M. J. Brouk, and H. A. Maiga. 1994. Nonstructural carbohydrate and undegradable protein sources in the diet: Growth responses of dairy heifers. J. Dairy Sci. 77:25952604. https://doi.org/10.3168/jds.S0022-0302(94)77200-3.

Ceballos-Marquez, A., H. W. Barkema, H. Stryhn, J. J. Wichtel, J. Neumann, A. Mella, J. Kruze, M. S. Espindola, and F. Wittwer. 2010. The effect of selenium supplementation before calving on early-lactation udder health in pastured dairy heifers. J. Dairy Sci. 93:4602-4612. https://doi.org/10.3168/jds.2010-3086.

Choi, Y. J., I. K. Han, J. H. Woo, H. J. Lee, K. Jang, K. H. Myung, and Y. S. Kim. 1997. Compensatory growth in dairy heifers: The effect of a compensatory growth pattern on growth rate and lactation performance. J. Dairy Sci. 80:519-524. https://doi.org/10 .3168/jds.S0022-0302(97)75965-4.

Clark, A. K., J. L. Albright, L. D. Muller, and F. G. Owen. 1984 Raising dairy replacement heifers: A review of NC-119 cooperative research. J. Dairy Sci. 67:3093-3098. https://doi.org/10.3168/jds .S0022-0302(84)81678-1.

Clark, B., and H. A. Keener. 1962. Effect of frequent feeding on weight gain response in young dairy heifers. J. Dairy Sci. 45:1199-1202. https://doi.org/10.3168/jds.S0022-0302(62)89596-4.

Coblentz, W. K., N. M. Esser, P. C. Hoffman, and M. S. Akins. 2015 Growth performance and sorting characteristics of corn silagealfalfa haylage diets with or without forage dilution offered to replacement Holstein dairy heifers. J. Dairy Sci. 98:8018-8034. https://doi.org/10.3168/jds.2015-9491.

Coffey, M. P., J. Hickey, and S. Brotherstone. 2006. Genetic aspects of growth of Holstein-Friesian dairy cows from birth to maturity. J. Dairy Sci. 89:322-329. https://doi.org/10.3168/jds.S0022 $-0302(06) 72097-5$.

Colovos, N. F., H. A. Keener, H. A. Davis, B. S. Reddy, and P. P. Reddy. 1963. Nutritive value of the dairy cattle ration as affected by different levels of urea and quality of ingredients. J. Dairy Sci 46:696-702. https://doi.org/10.3168/jds.S0022-0302(63)89125-0.

Cross, D. L., and B. F. Jenny. 1976. Turkey litter silage in rations for dairy heifers. J. Dairy Sci. 59:919-923. https://doi.org/10.3168/ jds.S0022-0302(76)84298-1.

Daccarett, M. G., E. J. Bortone, D. E. Isbell, J. L. Morrill, and A. M. Feyerherm. 1993. Performance of Holstein heifers fed $100 \%$ or more of National Research Council requirements. J. Dairy Sci 76:606-614. https://doi.org/10.3168/jds.S0022-0302(93)77381-6.

Daniels, K. J., S. S. Donkin, S. D. Eicher, E. A. Pajor, and M. M. Schutz. 2007. Prepartum milking of heifers influences future production and health. J. Dairy Sci. 90:2293-2301. https://doi.org/10 $.3168 /$ jds.2005-881.

Danscher, A. M., J. M. D. Enemark, E. Telezhenko, N. Capion, C. T. Ekstrøm, and M. B. Thoefner. 2009. Oligofructose overload induces lameness in cattle. J. Dairy Sci. 92:607-616. https://doi .org/10.3168/jds.2008-1271.

Danscher, A. M., T. H. Toelboell, and O. Wattle. 2010. Biomechanics and histology of bovine claw suspensory tissue in early acute laminitis. J. Dairy Sci. 93:53-62. https://doi.org/10.3168/jds.2009 -2038 .

Davis, H. P., and I. L. Hathaway. 1956. Comparative measurements of Holstein, Ayrshire, Guernsey, and Jersey females from birth to seven years. Agric. Exp. Stn. Res. Bul. 179. Univ. of Nebraska, Lincoln. 
Davis, H. P., and E. L. Willett. 1938. Relation between rate of growth and milk and fat production. J. Dairy Sci. 21:637-642. https://doi .org/10.3168/jds.S0022-0302(38)93013-9.

De Vries, A. 2004. Economics of delayed replacement when cow performance is seasonal. J. Dairy Sci. 87:2947-2958. https://doi.org/ 10.3168/jds.S0022-0302(04)73426-8.

Dobbelaar, P., R. J. Bouwstra, R. M. A. Goselink, R. Jorritsma, J. J. G. C. van den Borne, and E. H. J. M. Jansen. 2010. Effects of vitamin E supplementation on and the association of body condition score with changes in peroxidative biomarkers and antioxidants around calving in dairy heifers. J. Dairy Sci. 93:3103-3113. https://doi.org/10.3168/jds.2009-2677.

Donker, J. D., H. Singh, and H. W. Mohrenweiser. 1968. Forage evaluation. I. Performance of Holstein heifers fed only early-cut or latecut alfalfa hay on a free-choice basis. J. Dairy Sci. 51:362-366. https://doi.org/10.3168/jds.S0022-0302(68)86991-7.

Du, Z., R. W. Hemken, and R. J. Harmon. 1996. Copper metabolism of Holstein and Jersey cows and heifers fed diets high in cupric sulfate or copper proteinate. J. Dairy Sci. 79:1873-1880. https:// doi.org /10.3168/jds.S0022-0302(96)76555-4.

Duffield, T. F., K. E. Leslie, D. Sandals, K. Lissemore, B. W. McBride, J. H. Lumsden, P. Dick, and R. Bagg. 1999. Effect of prepartum administration of monensin in a controlled-release capsule on milk production and milk components in early lactation. J. Dairy Sci. 82:272-279. https://doi.org/10.3168/jds.S0022-0302(99)75233-1.

Duffield, T. F., D. Sandals, K. E. Leslie, K. Lissemore, B. W. McBride, J. H. Lumsden, P. Dick, and R. Bagg. 1998a. Effect of prepartum administration of monensin in a controlled-release capsule on postpartum energy indicators in lactating dairy cows. J. Dairy Sci. 81:2354-2361. https://doi.org/10.3168/jds.S0022-0302(98)70126 -2 .

Duffield, T. F., D. Sandals, K. E. Leslie, K. Lissemore, B. W. McBride, J. H. Lumsden, P. Dick, and R. Bagg. 1998b. Efficacy of monensin for the prevention of subclinical ketosis in lactating dairy cows. J. Dairy Sci. 81:2866-2873. https://doi.org/10.3168/jds.S0022 -0302(98)75846-1.

Eckles, C. H. 1920. The normal growth of dairy cattle. Missouri Agric. Exp. Stn. Res. Bul. 36. Univ. of Missouri, Columbia.

Eckles, C. H., T. W. Gullickson, and W. M. Neal. 1927. Maintenance requirements for calves tested by live weight methods. J. Dairy Sci 10:431-438. https://doi.org/10.3168/jds.S0022-0302(27)93860-0.

Esser, N. M., P. C. Hoffman, W. K. Coblentz, M. W. Orth, and K. A. Weigel. 2009. The effect of dietary phosphorus on bone development in dairy heifers. J. Dairy Sci. 92:1741-1749. https://doi.org/ 10.3168/jds.2008-1789.

Ettema, J. F., and J. E. P. Santos. 2004. Impact of age at calving on lactation, reproduction, health, and income in first-parity Holsteins on commercial farms. J. Dairy Sci. 87:2730-2742. https:// doi.org/10.3168/jds.S0022-0302(04)73400-1.

Ford, J. A., Jr., and C. S. Park. 2001. Nutritionally directed compensatory growth enhances heifer development and lactation potential. J. Dairy Sci. 84:1669-1678. https://doi.org/10.3168/jds.S0022 $-0302(01) 74602-4$.

Fox, D. G., M. E. Van Amburgh, and T. P. Tylutki. 1999. Predicting requirements for growth, maturity, and body reserves in dairy cattle. J. Dairy Sci. 82:1968-1977. https://doi.org/10.3168/jds.S0022 -0302(99)75433-0.

Gabler, M. T., and A. J. Heinrichs. 2003. Dietary protein to metabolizable energy ratios on feed efficiency and structural growth of prepubertal Holstein heifers. J. Dairy Sci. 86:268-274. https://doi org/10.3168/jds.S0022-0302(03)73605-4.

Gabler, M. T., P. R. Tozer, and A. J. Heinrichs. 2000. Development of a cost analysis spreadsheet for calculating the costs to raise a replacement dairy heifer. J. Dairy Sci. 83:1104-1109. https://doi .org/10.3168/jds.S0022-0302(00)74975-7.

Gardner, R. W., J. D. Schuh, and L. G. Vargus. 1977. Accelerated growth and early breeding of Holstein heifers. J. Dairy Sci. 60:1941-1948. https://doi.org/10.3168/jds.S0022-0302(77)84126 $-\mathrm{X}$.

Gardner, R. W., L. W. Smith, and R. L. Park. 1988. Feeding and management of dairy heifers for optimal lifetime productivity. J. Dairy
Sci. 71:996-999. https://doi.org/10.3168/jds.S0022-0302(88)79646 $-0$

Gill, G. S., and F. R. Allaire. 1976. Relationship of first lactation performance to lifetime production and economic efficiency. J. Dairy Sci. 59:1319-1324. https://doi.org/10.3168/jds.S0022 $-0302(76) 84362-7$.

Gomez, A., N. B. Cook, M. T. Socha, and D. Döpfer. 2015. Firstlactation performance in cows affected by digital dermatitis during the rearing period. J. Dairy Sci. 98:4487-4498. https://doi.org/10 $.3168 / \mathrm{jds} .2014-9041$.

Gordon, C. H. J. R. Dawson, L. A. Moore, and W. H. Hosterman. 1952. Feeding value of different grades of alfalfa hay for growing dairy heifers. J. Dairy Sci. 35:755-763. https://doi.org/10.3168/ jds.S0022-0302(52)93752-1.

Gordon, C. H., L. A. Moore, and W. H. Hosterman. 1954. The feeding value of U.S. no. 1 alfalfa hay and U.S. no. 2 alfalfa heavy timothy mixed hay. J. Dairy Sci. 37:1116-1122. https://doi.org/10.3168/ jds.S0022-0302(54)91375-2.

Gordon, C. H., L. A. Moore, and W. H. Hosterman. 1956. The relative feeding value of alfalfa hay and alfalfa light timothy mixed hay at approximately the U.S. no. 1 grade level. J. Dairy Sci. 39:11421148. https://doi.org/10.3168/jds.S0022-0302(56)94830-5.

Green, T. C., J. G. Jago, K. A. Macdonald, and G. C. Waghorn. 2013. Relationships between residual feed intake, average daily gain, and feeding behavior in growing dairy heifers. J. Dairy Sci. 96:30983107. https://doi.org/10.3168/jds.2012-6087.

Greter, A. M., E. K. Miller-Cushon, B. W. McBride, T. M. Widowski, T. F. Duffield, and T. J. DeVries. 2015. Short communication: Limit feeding affects behavior patterns and feeding motivation of dairy heifers. J. Dairy Sci. 98:1248-1254. https://doi.org/10.3168/ jds.2014-8879.

Greter, A. M., M. Prinsen, T. F. Duffield, B. W. McBride, T. M. Widowski, and T. J. DeVries. 2013. Growing dairy heifers prefer supplementary long straw when fed a nutrient-dense ration in a limited amount. J. Dairy Sci. 96:3950-3958. https://doi.org/10 $.3168 /$ jds.2013-6625.

Grummer, R. R., J. C. Winkler, S. J. Bertics, and V. A. Studer. 1994. Effect of propylene glycol dosage during feed restriction on metabolites in blood of prepartum Holstein heifers. J. Dairy Sci. 77:36183623. https://doi.org/10.3168/jds.S0022-0302(94)77306-9.

Gullickson, T. W., and C. H. Eckles. 1927. The relation of sunlight to the growth and development of calves. J. Dairy Sci. 10:87-94. https://doi.org/10.3168/jds.S0022-0302(27)93820-X.

Hammond, K. J., D. J. Humphries, L. A. Crompton, P. Kirton, and C. K. Reynolds. 2015. Effects of forage source and extruded linseed supplementation on methane emissions from growing dairy cattle of differing body weights. J. Dairy Sci. 98:8066-8077. https://doi .org/10.3168/jds.2015-9669.

Hansen, S. L., J. W. Spears, K. E. Lloyd, and C. S. Whisnant. 2006. Feeding a low manganese diet to heifers during gestation impairs fetal growth and development. J. Dairy Sci. 89:4305-4311. https:/ doi.org/10.3168/jds.S0022-0302(06)72477-8.

Hare, E., H. D. Norman, and J. R. Wright. 2006. Trends in calving ages and calving intervals for dairy cattle breeds in the United States. J. Dairy Sci. 89:365-370. https://doi.org/10.3168/jds .S0022-0302(06)72102-6.

Hart, E. B., G. Bohstedt, H. J. Deobald, and M. I. Wegner. 1939. The utilization of simple nitrogenous compounds such as urea and ammonium bicarbonate by growing calves. J. Dairy Sci. 22:785-798. https://doi.org/10.3168/jds.S0022-0302(39)92937-1.

Hart, E. B., E. V. McCollum, H. Steenbock, and G. C. Humphrey. 1911. Physiological effects on growth and reproduction of rations balanced from restricted sources. Wisconsin Agric. Exp. Stn. Res. Bul. 17. Univ. of Wisconsin, Madison.

Hayirli, A., R. R. Grummer, E. V. Nordheim, and P. M. Crump. 2002. Animal and dietary factors affecting feed intake during the prefresh transition period in Holsteins. J. Dairy Sci. 85:3430-3443. https://doi.org/10.3168/jds.S0022-0302(02)74431-7.

Hedges, J., R. W. Blowey, A. J. Packington, C. J. O'Callaghan, and L. E. Green. 2001. A longitudinal field trial of the effect of biotin 
on lameness in dairy cows. J. Dairy Sci. 84:1969-1975. https://doi .org/10.3168/jds.S0022-0302(01)74639-5.

Heinrichs, A. J., and G. L. Hargrove. 1987. Standards of weight and height for Holstein heifers. J. Dairy Sci. 70:653-660. https://doi .org/10.3168/jds.S0022-0302(87)80055-3.

Heinrichs, A. J., and G. L. Hargrove. 1991. Standards of weight and height for Guernsey and Jersey heifers. J. Dairy Sci. 74:1684-1689. https://doi.org/10.3168/jds.S0022-0302(91)78331-8.

Heinrichs, A. J., and G. L. Hargrove. 1994. Standards of weight and height for Ayrshire, Brown Swiss, and Milking Shorthorn heifers. J. Dairy Sci. 77:1676-1681. https://doi.org/10.3168/jds.S0022 $-0302(94) 77109-5$.

Heinrichs, A. J., C. M. Jones, S. M. Gray, P. A. Heinrichs, S. A. Cornelisse, and R. C. Goodling. 2013. Identifying efficient dairy heifer producers using production costs and data envelopment analysis. J. Dairy Sci. 96:7355-7362. https://doi.org/10.3168/jds.2012-6488.

Heinrichs, A. J., G. W. Rogers, and J. B. Cooper. 1992. Predicting body weight and wither height in Holstein heifers using body measurements. J. Dairy Sci. 75:3576-3581. https://doi.org/10.3168/ jds.S0022-0302(92)78134-X.

Heinrichs, A. J., and M. Vazquez-Anon. 1993. Changes in first lactation Dairy Herd Improvement records. J. Dairy Sci. 76:671-675. https://doi.org/10.3168/jds.S0022-0302(93)77390-7.

Heinrichs, A. J., S. J. Wells, H. S. Hurd, G. W. Hill, and D. A. Dargatz. 1994. The National Dairy Heifer Evaluation Project: A profile of heifer management practices in the United States. J. Dairy Sci. 77:1548-1555. https://doi.org/10.3168/jds.S0022-0302(94)77096 $-\mathrm{X}$.

Henry, W. A., and F. B. Morrison. 1915. Feeds and Feeding: A Handbook for the Student and Stockman. 15th ed. Henry-Morrison, Madison, WI.

Henry, W. A., and F. B. Morrison. 1923. Feeds and Feeding. 18th ed. Henry-Morrison, Madison, WI.

Hilton, J. H., J. W. Wilbur, and S. M. Hauge. 1932. A comparison between ground soybeans and linseed oilmeal as protein supplements for growing dairy calves. J. Dairy Sci. 15:277-281. https://doi.org/ 10.3168/jds.S0022-0302(32)93413-4.

Hoffman, P. C., N. M. Esser, L. M. Bauman, S. L. Denzine, M. Engstrom, and H. Chester-Jones. 2001. Short communication: Effect of dietary protein on growth and nitrogen balance of Holstein heifers. J. Dairy Sci. 84:843-847. https://doi.org/10.3168/jds.S0022 $-0302(01) 74542-0$.

Hoffman, P. C., and D. A. Funk. 1992. Applied dynamics of dairy replacement growth and management. J. Dairy Sci. 75:2504-2516. https://doi.org/10.3168/jds.S0022-0302(92)78012-6.

Hoffman, P. C., C. R. Simson, and M. Wattiaux. 2007. Limit feeding of gravid Holstein heifers: Effect on growth, manure nutrient excretion, and subsequent early lactation performance. J. Dairy Sci. 90:946-954. https://doi.org/10.3168/jds.S0022-0302(07)71578-3.

Hoffman, P. C., K. A. Weigel, and R. M. Wernberg. 2008. Evaluation of equations to predict dry matter intake of dairy heifers. J. Dairy Sci. 91:3699-3709. https://doi.org/10.3168/jds.2007-0644.

Huffman, C. F., C. W. Duncan, and C. C. Lightfoot. 1935. Vitamin D studies in cattle. I. The antirachitic value of hay in the ration of dairy cattle. J. Dairy Sci. 18:511-526. https://doi.org/10.3168/jds .S0022-0302(35)93169-1.

Huffman, C. F., C. S. Robinson, C. W. Duncan, L. W. Lamb, and M. F. Mason. 1933. A study of the phosphorus requirement of dairy cattle. I. Phosphorus requirement for growth and reproduction from three months of age to first calving. J. Dairy Sci. 16:203-223. https://doi.org/10.3168/jds.S0022-0302(33)93333-0.

Johnson, J. C., Jr., and W. C. McCormick. 1975. Ensiled diet containing processed municipal garbage and sorghum forage for heifers. J. Dairy Sci. 58:1672-1676. https://doi.org/10.3168/jds.S0022 $-0302(75) 84766-7$

Jones, I. R., C. H. Eckles, and L. S. Palmer. 1926. The role of vitamin A in the nutrition of calves. J. Dairy Sci. 9:119-139. https://doi .org/10.3168/jds.S0022-0302(26)93883-6.

Jukola, E., J. Hakkarainen, H. Saloniemi, and S. Sankari. 1996. Effect of selenium fertilization on selenium in feedstuffs and selenium, vitamin E, and $\beta$-carotene concentrations in blood of cattle. J. Dairy
Sci. 79:831-837. https://doi.org/10.3168/jds.S0022-0302(96)76431 -7 .

Kamal, M. M., M. Van Eetvelde, E. Depreester, M. Hostens, L. Vandaele, and G. Opsomer. 2014. Age at calving in heifers and level of milk production during gestation in cows are associated with the birth size of Holstein calves. J. Dairy Sci. 97:5448-5458. https:// doi.org/10.3168/jds.2014-7898.

Keener, H. A., F. E. Allen, N. F. Colovos, A. C. Paul, and H. A. Davis. 1958. Value of adding corn silage and limited quantities of hay to a grass silage, limited grain ration for dairy heifers. J. Dairy Sci. 41:429-437. https://doi.org/10.3168/jds.S0022-0302(58)90936-6.

Kelkar, C. N., and T. W. Gullickson. 1950. Importance of hay quality as indicated by feeding trials with identical twin dairy heifers. J. Dairy Sci. 33:288-292. https://doi.org/10.3168/jds.S0022 -0302(50)91902-3.

Kertz, A. F., B. A. Barton, and L. F. Reutzel. 1998. Relative efficiencies of wither height and body weight increase from birth until first calving in Holstein cattle. J. Dairy Sci. 81:1479-1482. https://doi .org/10.3168/jds.S0022-0302(98)75712-1.

Kertz, A. F., L. R. Prewitt, and J. M. Ballam. 1987. Increased weight gain and effects on growth parameters of Holstein heifer calves from 3 to 12 months of age. J. Dairy Sci. 70:1612-1622. https:// doi.org/10.3168/jds.S0022-0302(87)80189-3.

Keys, J. E., and L. W. Smith. 1981. Effect of poultry excreta and ground ear corn on growth, intake, and digestion of corn stover silage diets by yearling dairy heifers. J. Dairy Sci. 64:140-145. https://doi.org/10.3168/jds.S0022-0302(81)82540-4.

Kincaid, R. L., B. P. Chew, and J. D. Cronrath. 1997. Zinc oxide and amino acids as sources of dietary zinc for calves: Effects on uptake and immunity. J. Dairy Sci. 80:1381-1388. https://doi.org/10 .3168/jds.S0022-0302(97)76067-3.

King, W. A., G. D. O'Dell, and D. B. Roderick. 1957. Utilization of blackstrap molasses, urea in molasses, and ammoniated molasses by dairy heifers. J. Dairy Sci. 40:810-817. https://doi.org/10 .3168/jds.S0022-0302(57)94557-5.

Koenen, E. P. C., and A. F. Groen. 1996. Genetic analysis of growth patterns of black and white dairy heifers. J. Dairy Sci. 79:495-501. https://doi.org/10.3168/jds.S0022-0302(96)76391-9.

Krpálková, L., V. E. Cabrera, M. Vacek, M. Štípková, L. Stádník, and P. Crump. 2014. Effect of prepubertal and postpubertal growth and age at first calving on production and reproduction traits during the first 3 lactations in Holstein dairy cattle. J. Dairy Sci. 97:3017-3027. https://doi.org/10.3168/jds.2013-7419.

Kruger, J. H., and S. I. Bechdel. 1928. Studies in the normal depositions of minerals in the bones of dairy calves. J. Dairy Sci. 11:2434. https://doi.org/10.3168/jds.S0022-0302(28)93610-3.

Kutzer, T., M. Steilen, L. Gygax, and B. Wechsler. 2015. Habituation of dairy heifers to milking routine - Effects on human avoidance distance, behavior, and cardiac activity during milking. J. Dairy Sci. 98:5241-5251. https://doi.org/10.3168/jds.2014-8773.

Lammers, B. P., and A. J. Heinrichs. 2000. The response of altering the ratio of dietary protein to energy on growth, feed efficiency, and mammary development in rapidly growing prepubertal heifers. J. Dairy Sci. 83:977-983. https://doi.org/10.3168/jds.S0022 -0302(00)74962-9.

Lammers, B. P., A. J. Heinrichs, and R. S. Kensinger. 1999. The effects of accelerated growth rates and estrogen implants in prepubertal Holstein heifers on growth, feed efficiency, and blood parameters. J. Dairy Sci. 82:1746-1752. https://doi.org/10.3168/jds .S0022-0302(99)75405-6.

Lascano, G. J., A. J. Heinrichs, R. R. Gary, P. A. Topper, R. C. Brandt, A. Adviento-Borbe, and E. E. Fabian. 2015. Effects of forage-to-concentrate ratio and dietary fiber manipulation on gas emissions and olfactometry from manure of Holstein heifers. J. Dairy Sci. 98:1928-1937. https://doi.org/10.3168/jds.2014-8633.

Lascano, G. J., A. J. Heinrichs, and J. M. Tricarico. 2012. Substitution of starch by soluble fiber and Saccharomyces cerevisiae dose response on nutrient digestion and blood metabolites for precisionfed dairy heifers. J. Dairy Sci. 95:3298-3309. https://doi.org/10 $.3168 /$ jds.2011-5047. 
Lascano, G. J., L. E. Koch, and A. J. Heinrichs. 2016. Precision-feeding dairy heifers a high rumen-degradable protein diet with different proportions of dietary fiber and forage-to-concentrate ratios. J. Dairy Sci. 99:7175-7190. https://doi.org/10.3168/jds.2016-11190.

Lassiter, C. A., R. M. Grimes, C. W. Duncan, and C. F. Huffman. 1958. High-level urea feeding to dairy cattle. I. Effect of highlevel urea feeding on the growth and metabolism of growing dairy heifers without sulfur supplementation. J. Dairy Sci. 41:281-285. https://doi.org/10.3168/jds.S0022-0302(58)90904-4.

Lin, C. Y., A. J. McAllister, T. R. Batra, A. J. Lee, G. L. Roy, J. A. Vesely, J. M. Wauthy, and K. A. Winter. 1986. Production and reproduction of early and late bred dairy heifers. J. Dairy Sci. 69:760-768. https://doi.org/10.3168/jds.S0022-0302(86)80465-9.

Lin, C. Y., A. J. McAllister, T. R. Batra, A. J. Lee, G. L. Roy, J. A. Vesely, J. M. Wauthy, and K. A. Winter. 1988. Effects of early and late breeding of heifers on multiple lactation performance of dairy cows. J. Dairy Sci. 71:2735-2743. https://doi.org/10.3168/ jds.S0022-0302(88)79867-7.

Lofgreen, G. P., J. K. Loosli, and L. A. Maynard. 1951. The influence of energy intake on the nitrogen retention of growing calves. J. Dairy Sci. 34:911-915. https://doi.org/10.3168/jds.S0022 -0302(51)91800-0.

Marini, J. C., and M. E. Van Amburgh. 2005. Partition of nitrogen excretion in urine and the feces of Holstein replacement heifers. J. Dairy Sci. 88:1778-1784. https://doi.org/10.3168/jds.S0022 $-0302(05) 72852-6$.

Matthews, C. A., and M. H. Fohrman. 1954. Beltsville growth standards for Holstein cattle. Tech. Bul. No. 1099. USDA, Washington, DC.

Maynard, L. A., and L. C. Norris. 1923. A system of rearing dairy calves with limited use of milk. J. Dairy Sci. 6:483-499. https:// doi.org/10.3168/jds.S0022-0302(23)94112-3.

McCandlish, A. C. 1922. Studies in the growth and nutrition of dairy calves. J. Dairy Sci. 5:301-320. https://doi.org/10.3168/jds.S0022 -0302(22)94155-4.

McCandlish, A. C. 1923. Studies in the growth and nutrition of dairy calves. V. Milk as the sole ration for calves. J. Dairy Sci. 6:54-66. https://doi.org/10.3168/jds.S0022-0302(23)94060-9.

Mead, S. W., and H. Goss. 1935. Ruminant digestion without roughage. J. Dairy Sci. 18:163-170. https://doi.org/10.3168/jds.S0022 -0302(35)93130-7.

Mead, S. W., and W. M. Regan. 1931. Deficiencies in rations devoid of roughage for calves. J. Dairy Sci. 14:283-293. https://doi.org/ 10.3168/jds.S0022-0302(31)93473-5.

Miller-Cushon, E. K., J. P. Vogel, and T. J. DeVries. 2015. Short communication: Feed sorting of dairy heifers is influenced by method of dietary transition. J. Dairy Sci. 98:2687-2692. https://doi.org/ 10.3168/jds.2014-8782.

Mills, R. C., A. N. Booth, G. Bohstedt, and E. B. Hart. 1942. The utilization of urea by ruminants as influenced by the presence of starch in the ration. J. Dairy Sci. 25:925-929. https://doi.org/10 .3168/jds.S0022-0302(42)95356-6.

Mills, R. C., C. C. Lardinois, I. W. Rupel, and E. B. Hart. 1944. Utilization of urea and growth of heifer calves with corn molasses or cane molasses as the only readily available carbohydrate in the ration. J. Dairy Sci. 27:571-578. https://doi.org/10.3168/jds.S0022 -0302(44)92634-2.

Minor, D. J., S. L. Trower, B. D. Strang, R. D. Shaver, and R. R. Grummer. 1998. Effects of nonfiber carbohydrate and niacin on periparturient metabolic status and lactation of dairy cows. J. Dairy Sci. 81:189-200. https://doi.org/10.3168/jds.S0022-0302(98)75566 $-3$.

Mohd Nor, N., W. Steeneveld, T. van Werven, M. C. M. Mourits, and H. Hogeveen. 2013. First-calving age and first-lactation milk production on Dutch dairy farms. J. Dairy Sci. 96:981-992. https:// doi.org/10.3168/jds.2012-5741.

Montgomery, M. J., and B. R. Baumgardt. 1965a. Regulation of food intake in ruminants. 1. Pelleted rations varying in energy concentration. J. Dairy Sci. 48:569-574. https://doi.org/10.3168/jds .S0022-0302(65)88286-8.
Montgomery, M. J., and B. R. Baumgardt. 1965b. Regulation of food intake in ruminants. 2. Rations varying in energy concentration and physical form. J. Dairy Sci. 48:1623-1628. https://doi.org/10 .3168/jds.S0022-0302(65)88539-3.

Moore, S. J., M. J. VandeHaar, B. K. Sharma, T. E. Pilbeam, D. K Beede, H. F. Bucholtz, J. S. Liesman, R. L. Horst, and J. P. Goff. 2000. Effects of altering dietary cation-anion difference on calcium and energy metabolism in peripartum cows. J. Dairy Sci. 83:20952104. https://doi.org/10.3168/jds.S0022-0302(00)75091-0.

Mourits, M. C. M., A. A. Dijkhuizen, R. B. M. Huirne, and D. T. Galligan. 1997. Technical and economic models to support heifer management decisions: Basic concepts. J. Dairy Sci. 80:1406-1415. https://doi.org/10.3168/jds.S0022-0302(97)76070-3.

Mourits, M. C. M., D. T. Galligan, A. A. Dijkhuizen, and R. B. M. Huirne. 2000. Optimization of dairy heifer management decisions based on production conditions of Pennsylvania. J. Dairy Sci. 83:1989-1997. https://doi.org/10.3168/jds.S0022-0302(00)75076 -4 .

NRC. 1971. Nutrient Requirements of Dairy Cattle. 4th rev. ed. Natl. Acad. Sci., Washington, DC.

NRC. 1989. Nutrient Requirements of Dairy Cattle. 6th rev. ed. Natl. Acad. Press, Washington, DC.

NRC. 1996. Nutrient Requirements of Beef Cattle. 7th rev. ed. Natl. Acad. Sci., Washington, DC.

NRC. 2001. Nutrient Requirements of Dairy Cattle. 7th rev. ed. Natl. Acad. Press, Washington, DC.

Nennich, T. D., J. H. Harrison, L. M. VanWieringen, D. Meyer, A J. Heinrichs, W. P. Weiss, N. R. St-Pierre, R. L. Kincaid, D. L. Davidson, and E. Block. 2005. Prediction of manure and nutrient excretion from dairy cattle. J. Dairy Sci. 88:3721-3733. https://doi .org/10.3168/jds.S0022-0302(05)73058-7.

Nilforooshan, M. A., and M. A. Edriss. 2004. Effect of age at first calving on some productive and longevity traits in Iranian Holsteins of the Isfahan province. J. Dairy Sci. 87:2130-2135. https://doi.org/ 10.3168/jds.S0022-0302(04)70032-6.

Niss, D. B., M. S. Herskin, A. M. Danscher, and M. B. Thoefner. 2009. Short communication: Rising and lying behavior of heifers before and after alimentary oligofructose overload. J. Dairy Sci. 92:617-620. https://doi.org/10.3168/jds.2008-1150.

Noller, C. H., A. G. Castro, W. E. Wheeler, D. L. Hill, and N. J. Moeller. 1977. Effect of phosphorus supplementation on growth rate, blood minerals, and conception rate of dairy heifers. J. Dairy Sci. 60:1932-1940. https://doi.org/10.3168/jds.S0022 $-0302(77) 84125-8$.

Okura, N., N. Yamagishi, Y. Naito, K. Kanno, and M. Koiwa. 2004. Technical note: Vaginal absorption of $1,25(\mathrm{OH})_{2} \mathrm{D}_{3}$ in cattle. J. Dairy Sci. 87:2416-2419. https://doi.org/10.3168/jds.S0022 -0302(04)73364-0

Oliveira, A. S., D. C. Abreu, M. A. Fonseca, and P. M. B. Antoniassi. 2013. Short communication: Development and evaluation of predictive models of body weight for crossbred Holstein-Zebu dairy heifers. J. Dairy Sci. 96:6697-6702. https://doi.org/10.3168/jds 2013-6988.

Ospina, P. A., D. V. Nydam, T. Stokol, and T. R. Overton. 2010 Associations of elevated nonesterified fatty acids and beta-hydroxybutyrate concentrations with early lactation reproductive performance and milk production in transition dairy cattle in the northeastern United States. J. Dairy Sci. 93:1596-1603. https:// doi.org/10.3168/jds.2009-2852.

Park, C. S., R. B. Danielson, B. S. Kreft, S. H. Kim, Y. S. Moon, and W. L. Keller. 1998. Nutritionally directed compensatory growth and effects on lactation potential of developing heifers. J. Dairy Sci. 81:243-249. https://doi.org/10.3168/jds.S0022-0302(98)75572 $-9$.

Petersson-Wolfe, C. S., K. E. Leslie, T. Osborne, B. W. McBride, R. Bagg, G. Vessie, P. Dick, and T. F. Duffield. 2007. Effect of monensin delivery method on dry matter intake, body condition score, and metabolic parameters in transition dairy cows. J. Dairy Sci. 90:1870-1879. https://doi.org/10.3168/jds.2006-402. 
Petit, H. V., and Y. Yu. 1993. Use of protein supplements for dairy heifers fed fresh grass. J. Dairy Sci. 76:798-802. https://doi.org/10 .3168/jds.S0022-0302(93)77403-2.

Pirlo, G., F. Miglior, and M. Speroni. 2000. Effect of age at first calving on production traits and on difference between milk yield returns and rearing costs in Italian Holsteins. J. Dairy Sci. 83:603608. https://doi.org/10.3168/jds.S0022-0302(00)74919-8.

Plum, M., and J. L. Lush. 1934. Freshening ages of purebred cows in Iowa cow testing associations. J. Dairy Sci. 17:625-638. https:// doi.org/10.3168/jds.S0022-0302(34)93281-1.

Plum, M., B. N. Singh, and A. B. Schultze. 1952. Relationship between early rate of growth and butterfat production in dairy cattle. J. Dairy Sci. 35:957-962. https://doi.org/10.3168/jds.S0022 $-0302(52) 93781-8$

Powell, R. L. 1985. Trend of age at first calving. J. Dairy Sci. 68:768 772. https://doi.org/10.3168/jds.S0022-0302(85)80886-9.

Quigley, J. D., III, R. E. James, and M. L. McGilliard. 1986a. Dry matter intake in dairy heifers. 1. Factors affecting intake of heifers under intensive management. J. Dairy Sci. 69:2855-2862. https:// doi.org/10.3168/jds.S0022-0302(86)80739-1.

Quigley, J. D., III, R. E. James, and M. L. McGilliard. 1986b. Dry matter intake in dairy heifers. 2. Equations to predict intake of heifers under intensive management. J. Dairy Sci. 69:2863-2867. https://doi.org/10.3168/jds.S0022-0302(86)80740-8.

Rabelo, E., R. L. Rezende, S. J. Bertics, and R. R. Grummer. 2003. Effects of transition diets varying in dietary energy density on lactation performance and ruminal parameters of dairy cows. J. Dairy Sci. 86:916-925. https://doi.org/10.3168/jds.S0022-0302(03)73674 -1 .

Rabiansky, P. A., L. R. McDowell, J. Velasquez-Pereira, N. S. Wilkinson, S. S. Percival, F. G. Martin, D. B. Bates, A. B. Johnson, T. R. Batra, and E. Salgado-Madriz. 1999. Evaluating copper lysine and copper sulfate sources for heifers. J. Dairy Sci. 82:2642-2650. https://doi.org/10.3168/jds.S0022-0302(99)75521-9.

Ragsdale, A. C. 1934. Growth standards for dairy cattle. Missouri Agric. Exp. Stn. Bul. 336. Univ. of Missouri, Columbia.

Ray, P. P., C. Shang, R. E. Pearson, and K. F. Knowlton. 2012. Disappearance of infused phytate from the large intestine of dairy heifers. J. Dairy Sci. 95:5927-5935. https://doi.org/10.3168/jds.2012 $-5363$.

Reid, J. T., and J. Robb. 1971. Relationship of body composition to energy intake and energetic efficiency. J. Dairy Sci. 54:553-564. https://doi.org/10.3168/jds.S0022-0302(71)85887-3.

Rivera, J. D., S. E. Bachman, M. E. Hubbert, M. E. Branine, R. L. Horst, S. N. Williams, and M. L. Galyean. 2005. Short communication: Serum and tissue concentrations of vitamin D metabolites in beef heifers after buccal dosing of 25-hydroxyvitamin D. J. Dairy Sci. 88:1364-1369. https://doi.org/10.3168/jds.S0022 -0302(05)72803-4.

Salmon, W. D., and W. H. Eaton. 1925. Effect of bone meal on growth of dairy heifers. J. Dairy Sci. 8:312-317. https://doi.org/10.3168/ jds.S0022-0302(25)93966-5.

Scaletti, R. W., and R. J. Harmon. 2012. Effect of dietary copper source on response to coliform mastitis in dairy cows. J. Dairy Sci. 95:654-662. https://doi.org/10.3168/jds.2011-4435.

Scaletti, R. W., D. S. Trammell, B. A. Smith, and R. J. Harmon. 2003. Role of dietary copper in enhancing resistance to Escherichia coli mastitis. J. Dairy Sci. 86:1240-1249. https://doi.org/10.3168/jds .S0022-0302(03)73708-4.

Schultz, L. H. 1969. Relationship of rearing rate of dairy heifers to mature performance. J. Dairy Sci. 52:1321-1329. https://doi.org/ 10.3168/jds.S0022-0302(69)86746-9.

Simerl, N. A., C. J. Wilcox, W. W. Thatcher, and F. G. Martin. 1991. Prepartum and peripartum reproductive performance of dairy heifers freshening at young ages. J. Dairy Sci. 74:1724-1729. https://doi.org/10.3168/jds.S0022-0302(91)78335-5.

Spears, J. W., C. S. Whisnant, G. B. Huntington, K. E. Lloyd, R. S. Fry, K. Krafka, A. Lamptey, and J. Hyda. 2012. Chromium propionate enhances insulin sensitivity in growing cattle. J. Dairy Sci. 95:2037-2045. https://doi.org/10.3168/jds.2011-4845.
Steen, T. M., J. D. Quigley III, R. N. Heitmann, and J. D. Gresham. 1992. Effects of lasalocid and undegradable protein on growth and body composition of Holstein heifers. J. Dairy Sci. 75:2517-2523. https://doi.org/10.3168/jds.S0022-0302(92)78013-8.

Suarez-Mena, F. X., G. J. Lascano, and A. J. Heinrichs. 2013. Chewing activities and particle size of rumen digesta and feces of precision-fed dairy heifers fed different forage levels with increasing levels of distillers grains. J. Dairy Sci. 96:5184-5193. https://doi .org/10.3168/jds.2012-6155.

Sumner, J. M., F. Valdez, and J. P. McNamara. 2007. Effects of chromium propionate on response to an intravenous glucose tolerance test in growing Holstein heifers. J. Dairy Sci. 90:3467-3474. https://doi.org/10.3168/jds.2006-623.

Sutherland, M. A., and F. J. Huddart. 2012. The effect of training first-lactation heifers to the milking parlor on the behavioral reactivity to humans and the physiological and behavioral responses to milking and productivity. J. Dairy Sci. 95:6983-6993. https://doi .org/10.3168/jds.2011-5211.

Swanson, E. W. 1971. Feed energy requirements for different rates of growth of dairy heifers. J. Dairy Sci. 54:217-223. https://doi.org/ 10.3168/jds.S0022-0302(71)85815-0.

Swanson, E. W., B. J. Bearden, E. W. Culvahouse, and J. T. Miles. 1967. Restricting growth of cattle without depressing lactation. J. Dairy Sci. 50:863-869. https://doi.org/10.3168/jds.S0022 -0302(67)87536-2.

Swanson, E. W., and S. A. Hinton. 1964. Effect of seriously restricted growth upon lactation. J. Dairy Sci. 47:267-272. https://doi.org/ 10.3168/jds.S0022-0302(64)88638-0.

Swartz, L. A., A. J. Heinrichs, G. A. Varga, and L. D. Muller. 1991. Effects of varying dietary undegradable protein on dry matter intake, growth, and carcass composition of Holstein calves. J. Dairy Sci. 74:3884-3890. https://doi.org/10.3168/jds.S0022-0302(91)78581 -0 .

Thoefner, M. B., C. C. Pollitt, A. W. van Eps, G. J. Milinovich, D. J. Trott, O. Wattle, and P. H. Andersen. 2004. Acute bovine laminitis: A new induction model using alimentary oligofructose overload. J. Dairy Sci. 87:2932-2940. https://doi.org/10.3168/jds .S0022-0302(04)73424-4.

Thoefner, M. B., O. Wattle, C. C. Pollitt, K. R. French, and S. S. Nielsen. 2005. Histopathology of oligofructose-induced acute laminitis in heifers. J. Dairy Sci. 88:2774-2782. https://doi.org/10 $.3168 /$ jds.S0022-0302(05)72957-X.

Thurston, L. M., C. H. Eckles, and L. S. Palmer. 1926. The role of the antiscorbutic vitamin in the nutrition of calves. J. Dairy Sci. 9:37-49. https://doi.org/10.3168/jds.S0022-0302(26)93875-7.

Touchberry, R. W. 1951. Genetic correlations between five body measurements, weight, type and production in the same individual among Holstein cows. J. Dairy Sci. 34:242-255. https://doi.org/10 .3168/jds.S0022-0302(51)91701-8.

Tozer, P. R. 2000. Least-cost ration formulations for Holstein dairy heifers by using linear and stochastic programming. J. Dairy Sci 83:443-451. https://doi.org/10.3168/jds.S0022-0302(00)74901-0.

Tozer, P. R., and A. J. Heinrichs. 2001. What affects the costs of raising replacement dairy heifers: A multiple-component analysis. J. Dairy Sci. 84:1836-1844. https://doi.org/10.3168/jds.S0022 $-0302(01) 74623-1$.

Tyler, P. J., and K. A. Cummins. 2003. Effect of dietary ascorbyl2-phosphate on immune function after transport to a feeding facility. J. Dairy Sci. 86:622-629. https://doi.org/10.3168/jds.S0022 -0302(03)73640-6.

Van Amburgh, M. E., D. G. Fox, D. M. Galton, D. E. Bauman, and L. E. Chase. 1998. Evaluation of National Research Council and Cornell Net Carbohydrate and Protein Systems for predicting requirements of Holstein heifers. J. Dairy Sci. 81:509-526. https:// doi.org/10.3168/jds.S0022-0302(98)75603-6.

Van de Stroet, D. L., J. A. Calderón Díaz, K. J. Stalder, A. J. Heinrichs, and C. D. Dechow. 2016. Association of calf growth traits with production characteristics in dairy cattle. J. Dairy Sci. 99:8347-8355. https://doi.org/10.3168/jds.2015-10738.

VandeHaar, M. J., G. Yousif, B. K. Sharma, T. H. Herdt, R. S. Emery, M. S. Allen, and J. S. Liesman. 1999. Effect of energy and protein 
density of prepartum diets on fat and protein metabolism of dairy cattle in the periparturient period. J. Dairy Sci. 82:1282-1295. https://doi.org/10.3168/jds.S0022-0302(99)75351-8.

Ward, J. D., J. W. Spears, and E. B. Kegley. 1996. Bioavailability of copper proteinate and copper carbonate relative to copper sulfate in cattle. J. Dairy Sci. 79:127-132. https://doi.org/10.3168/jds .S0022-0302(96)76343-9.

Wegner, M. I., A. N. Booth, G. Bohstedt, and E. B. Hart. 1941a. Preliminary observations on chemical changes of rumen ingesta with and without urea. J. Dairy Sci. 24:51-56. https://doi.org/10.3168/ jds.S0022-0302(41)95383-3.

Wegner, M. I., A. N. Booth, G. Bohstedt, and E. B. Hart. 1941b. The utilization of urea by ruminants as influenced by the level of protein in the ration. J. Dairy Sci. 24:835-844. https://doi.org/10 .3168/jds.S0022-0302(41)95466-8.

Weiss, W. P., J. M. Pinos-Rodríguez, and M. T. Socha. 2010. Effects of feeding supplemental organic iron to late gestation and early lactation dairy cows. J. Dairy Sci. 93:2153-2160. https://doi.org/ 10.3168/jds.2010-3051.

White, G. C. 1917. Age at first calving. J. Dairy Sci. 1:139-147. https://doi.org/10.3168/jds.S0022-0302(17)94366-8.

Willard, H. S. 1932. A study of the effects of alfalfa hay and irrigated pasture on growth of Holstein heifers. J. Dairy Sci. 15:435-444. https://doi.org/10.3168/jds.S0022-0302(32)93434-1.

Willard, H. S. 1938. Hay consumption of Holstein calves. J. Dairy Sci. 21:153-160. https://doi.org/10.3168/jds.S0022-0302(38)95629-2.

Wise, G. H., T. W. Gullickson, and W. E. Petersen. 1939. Value of various vitamins and inorganic salts for overcoming symptoms manifested in calves restricted to a whole milk ration. J. Dairy Sci. 22:573-582. https://doi.org/10.3168/jds.S0022-0302(39)92913-9.

Woll, F. W. 1918. Alfalfa as a sole feed for dairy cattle. J. Dairy Sci. 1:447-461. https://doi.org/10.3168/jds.S0022-0302(18)94391-2.

Yost, G. P., J. D. Arthington, L. R. McDowell, F. G. Martin, N. S. Wilkinson, and C. K. Swenson. 2002. Effect of copper source and level on the rate and extent of copper repletion in Holstein heifers. J. Dairy Sci. 85:3297-3303. https://doi.org/10.3168/jds.S0022 $-0302(02) 74418-4$

Zanton, G. I., and A. J. Heinrichs. 2005. Meta-analysis to assess effect of prepubertal average daily gain of Holstein heifers on firstlactation production. J. Dairy Sci. 88:3860-3867. https://doi.org/ 10.3168/jds.S0022-0302(05)73071-X.

Zanton, G. I., and A. J. Heinrichs. 2008a. Analysis of nitrogen utilization and excretion in growing dairy cattle. J. Dairy Sci. 91:15191533. https://doi.org/10.3168/jds.2007-0624.

Zanton, G. I., and A. J. Heinrichs. 2008b. Rumen digestion and nutritional efficiency of dairy heifers limit-fed a high forage ration to four levels of dry matter intake. J. Dairy Sci. 91:3579-3588. https://doi.org/10.3168/jds.2008-1210.

Zanton, G. I., and A. J. Heinrichs. 2009. Digestion and nitrogen utilization in dairy heifers limit-fed a low or high forage ration at four levels of nitrogen intake. J. Dairy Sci. 92:2078-2094. https://doi .org/10.3168/jds.2008-1712.

Zanton, G. I., and A. J. Heinrichs. 2016. Efficiency and rumen responses in younger and older Holstein heifers limit-fed diets of differing energy density. J. Dairy Sci. 99:2825-2836. https://doi .org/10.3168/jds.2015-10316. 


\section{APPENDIX}

Table A1. Major milestones in the study of dairy heifer nutrition and management

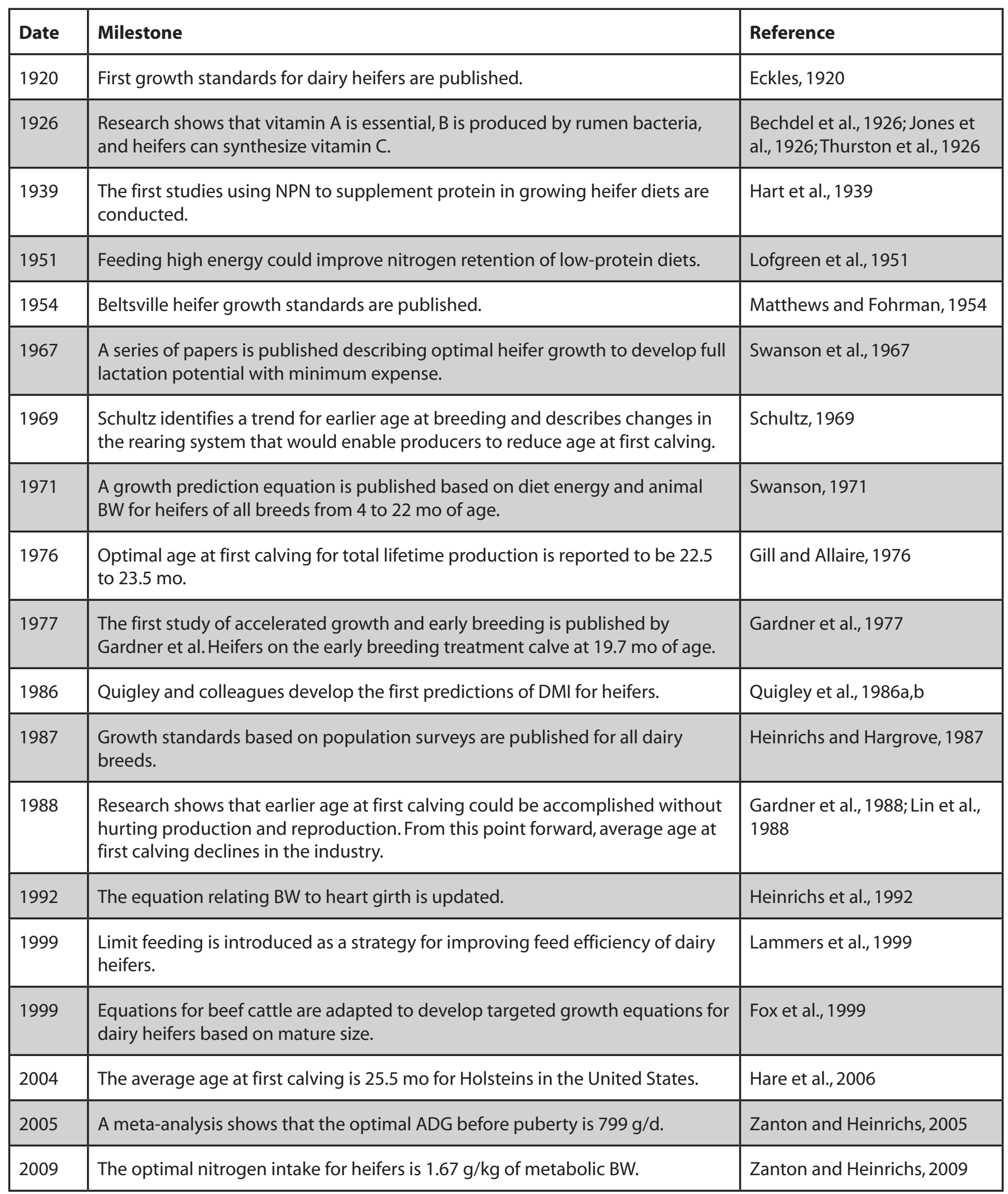

